\title{
PERSEPSI PEREMPUAN DI KOTA PADANG TENTANG PERCERAIAN
}

\author{
Rozalinda \& Nurhasanah \\ Fakultas Syariah IAIN Imam Bonjol \\ Jl. Mahmud Yunus, Lubuk Lintah, Padang, 25153 \\ e-mail: roza_linda32@yahoo.com,nurhasanahnur@gmail.com
}

\begin{abstract}
Abstrak: Islam mensyariatkan perkawinan dengan tujuan mendapatkan keluarga bahagia. Namun, kenyataannya, sering terjadi perselisihan dalam keluarga yang tidak dapat didamaikan, yang berujung pada perceraian. Penelitian ini bertujuan mengungkapkan faktor penyebab meningkatnya perkara gugatan cerai di Pengadilan Agama Padang dan menggali persepsi perempuan di Kota Padang tentang perceraian. Dengan menggunakan metode kualitatif, data dihimpun dari dokumen Pengadilan Agama Kelas I A Padang dan wawancara dengan perempuan yang mengajukan gugatan cerai, hakim, panitera, pengacara, dan tokoh perempuan. Temuan penelitian menunjukkan bahwa faktor penyebab meningkatnya gugatan cerai adalah membaiknya tingkat pendidikan, kesadaran hukum, peluang berkarier dan perubahan stigma masyarakat terhadap perempuan yang bercerai. Selain itu, perempuan di Kota Padang berpendapat bahwa cerai bukanlah hal yang tabu dan menakutkan, karena juga dilindungi undangundang sehingga dianggap sebagai solusi ampuh dalam menyelesaikan konflik keluarga.
\end{abstract}

Abstract: Woman Perception on Divorce in Padang Central City. Islam set down marriage rule as a means of acquiring happiness. In reality, however, it marriage conflict may occur, and often cannot be resolved and that it leads to divorce. This study is a qualitative study seeking to reveal the causes of increasing divorce rate in the Religious Court of Padang, and to unveil women's perceptions concerning divorce in Padang. By using qualitative method, the data is collected from the documents of the Grade I A Religious Court of Padang, and interviews with those women who file legal divorce suit, judges, clerks, lawyers, and women scholars. The findings reveal that the undelying factors of divorce rate increase are due to women's education improvement, increasing legal awareness, the availability of career opportunities, changing social stigma against divorced women and weakening understanding of religious values among women. Women in Padang perceive that divorce is no longer a taboo and embarrassing, since grants womens' rights to file divorce in the court, and thus seen as an alternative solution to.

Kata Kunci: perceraian, gugatan cerai, khuluk, perempuan, pengadilan agama 


\section{Pendahuluan}

Pernikahan merupakan sesuatu yang disyari'atkan agama Islam sebagaimana terdapat dalam al-Qur'an dan hadis Rasul-Nya. Di antara tujuan pernikahan adalah terwujudnya keluarga bahagia, tenang, tentram dan kekal. Setiap pasangan yang menikah tentulah mengharapkan hal ini, namun dalam kenyataannya tidak semua keluarga memperolehnya. Tidak jarang terjadi, di antara suami isteri terjadi ketidakharmonisan atau perselisihan yang tidak bisa didamaikan, atau terdapat hal-hal yang menyebabkan suami dan isteri tidak dapat lagi mempertahankan hubungan mereka. ${ }^{1}$

Sebagai solusi terakhir dari permasalahan tersebut Islam membolehkan terjadinya perceraian antara suami isteri. Meskipun sebenarnya perceraian itu merupakan sesuatu yang tidak diharapkan, sehingga Nabi menyebut perceraian itu sebagai perbuatan halal tetapi dibenci Allah. Bila dilihat dari segi siapa yang menghendaki terjadinya perceraian, perceraian dapat dibagi dua, yaitu perceraian karena keinginan suami yang disebut dengan thalak dan perceraian karena keinginan istri (khuluk). ${ }^{2}$ Di Indonesia, sesuai dengan peraturan perundang-undangan yang berlaku, perceraian atas kehendak suami disebut dengan cerai talak, sedangkan cerai atas kehendak isteri disebut cerai gugat. ${ }^{3}$

Pada umumnya, perceraian lebih banyak terjadi karena kehendak suami, bukan atas kehendak isteri. Hal ini disebabkan karena posisi suami di dalam keluarga jauh lebih kuat dibandingkan istri. Namun, data statistik Badan Peradilan Agama Mahkamah Agung RI menyebutkan, pada tahun 2009 perkara perceraian yang diputus Pengadilan Agama/ Mahkamah Syar'iyah mencapai 223.371 perkara. Sementara itu, perkara cerai gugat berjumlah 150.000 perkara. Ini berarti 65\% dari perkara cerai yang diproses di Pengadilan Agama di seluruh Indonesia adalah cerai gugat. ${ }^{4}$ Berdasarkan data yang diperoleh dari Pengadilan Agama Kelas I A Padang ditemukan permasalahan yang sama, di mana angka gugat cerai jauh lebih banyak jika dibandingkan dengan cerai talak, seperti ditunjukkan pada tabel di bawah ini:

${ }^{1}$ Sudarsono, Hukum Perkawinan Nasional (Jakarta: Rineka Cipta, 1991), h. 288.

${ }^{2}$ Arso Sasroatmodjo dan A. Wasit Aulawi, Hukum Perkawinan di Indonesia, Cet. 2 (Jakarta: Bulan Bintang, 1978), Cet. ke-2, h. 59-60.

${ }^{3}$ Iskandar Ritonga, Hak-Hak Wanita Dalam Putusan Peradilan Agama (Jakarta: Program Peningkatan Kualitas Pelayanan Publik Ditjen Bimas Islam dan Penyelenggaraan Haji Departemen Agama RI, 2005), h. 215.

${ }^{4}$ Melonjaknya Angka Perceraian Jadi Sorotan Lagi dalam http://www.badilag.net/2010/ 5/10, diakses 16 Juni 2011. 
Tabel 1.

Perkembangan Perkara di Pengadilan Agama Kelas I A Padang

\begin{tabular}{|c|c|c|c|c|c|}
\hline Tahun & Jumlah Perkara & \multicolumn{2}{|c|}{ Permohonan Cerai } & \multicolumn{2}{c|}{ Gugatan Cerai } \\
\hline 2008 & 771 & 261 & $38 \%$ & 424 & $62 \%$ \\
\hline 2009 & 728 & 246 & $35 \%$ & 462 & $65 \%$ \\
\hline 2010 & 851 & 278 & $33 \%$ & 573 & $67 \%$ \\
\hline 2011 & 851 & 328 & $35 \%$ & 615 & $65 \%$ \\
\hline 2012 & 1042 & 354 & $34 \%$ & 688 & $66 \%$ \\
\hline Total & 3702 & 1298 & $35 \%$ & 2390 & $65 \%$ \\
\hline
\end{tabular}

Sumber: Laporan Tahunan Pengadilan Agama Kelas I A Padang, tahun 2013

Kasus perceraian umumnya dipicu oleh faktor ekonomi, poligami, krisis akhlak, cemburu, tidak ada tanggung jawab, kawin di bawah umur, cacat biologis, kekerasan dalam rumah tangga, kurang harmonisnya rumah tangga dan campur tangan pihak ketiga. Sementara itu, angka cerai gugat di Pengadilan Agama Kelas I A Padang meningkat umumnya lebih didominasi oleh kurang bertanggungjawabnya suami pada istri dan keluarga atau faktor ekonomi. Hal inilah yang menyebabkan pihak perempuan (istri) memilih berpisah dengan suaminya. ${ }^{5}$ Kondisi demikian menimbulkan sejumlah pertanyaan, apakah sebenarnya yang menyebabkan meningkatnya angka cerai gugat perempuan di Kota Padang. Apakah meningkatnya angka cerai gugat menunjukkan perubahan pemahaman perempuan terhadap perceraian? Sehingga sesuatu yang dianggap tabu dan memalukan di kalangan masyarakat Minangkabau, dengan falsafah adat basandi syarak, syarak basandi kitabullah sudah dianggap hal yang wajar. Berdasarkan latar belakang masalah di atas, penelitian ini dilakukan dengan tujuan menemukan: 1) Faktor-faktor yang memengaruhi peningkatan angka gugagatan cerai di Kota Padang, 2) Persepsi perempuan di Kota Padang terhadap perceraian. Penelitian ini dibatasi pada perkara gugatan cerai di Pengadilan Agama Kelas I A Padang tahun 2008 sampai dengan tahun 2012.

\section{Metode}

Penelitian ini merupakan penelitian kualitatif yang berusaha mengungkapkan secara mendalam faktor penyebab meningkatnya perkara gugatan cerai di Pengadilan Agama Kelas I A Padang dan persepsi perempuan di kota Padang terhadap perceraian. Untuk sampai pada tujuan penelitian, maka penelitian ini mengikuti langkah-langkah sebagai berikut: (1) Menelusuri dan menjaring data di Pengadilan Agama Kelas I A Padang yang berkaitan dengan perkara gugatan cerai yang terdapat pada buku register perkara dan arsip putusan

${ }^{5}$ Wawancara dengan Yelti Multi, Panitera Muda Hukum Pengadilan Agama Kelas IA Padang, Padang, 25 Mei 2012. 
PA. (2) Menelusuri statisitik perkara gugatan cerai di Pengadilan Agama Kelas I A Padang. (3) Mempelajari dan menela'ah keputusan hakim tentang gugatan cerai. (4) Melakukan wawancara dengan perempuan bercerai. (4) Langkah selanjutnya, melakukan wawancara dengan panitera dan hakim yang menyidangkan perkara cerai gugat (5) Kemudian, wawancara dengan tokoh perempuan Sumatera Barat. (6) Setelah data terkumpul baik melalui dokumentasi dan wawancara, langkah selanjutnya adalah mengolah data, menganalisis dan melakukan proses editing.

Sumber data pada penelitian ini adalah perempuan yang bercerai yang telah menggugat cerai suaminya ke Pengadilan Agama kelas I A Padang. Data ini dihimpun berdasarkan daftar registrasi perkara gugatan cerai yang masuk ke pengadilan sejak tahun 2008-2012. Karena banyaknya sumber data yang mencapai 2390 perkara, maka sumber data dipilah secara acak (random sampling) dengan mempertimbangkan aspek pendidikan (terdidik atau tidak terdidik), pekerjaan (bekerja atau tidak bekerja), tempat tinggal (tinggal bersama keluarga besar atau hidup mandiri). Penelitian ini juga menjaring data dari Hakim dan Panitera Pengadilan Agama Kelas I A Padang. Di samping itu, data juga diperoleh dari Pengacara Syariah, Pakar dan Konsultan Keluarga Sakinah, serta Ketua Bundo Kanduang Sumatera Barat.

Mengacu kepada analisis data kualitatif data yang diperoleh dari hasil wawancara, observasi, dan dokumen resmi maka langkah pertama yang dilakukan dalam analisis data kualitatif dalam penelitian ini adalah mengembangkan deskripsi yang komprehensif dan teliti terhadap hasil penelitian. Langkah kedua adalah mengklasifikasi data, yakni memilahmilah data dan memadukanya kembali. ${ }^{6}$ Klasifikasi dilakukan agar dapat membuat perbandingan antara data yang satu dengan data yang lainnya seperti data yang didapatkan dari seorang responden dengan responden lainnya, membandingkan data yang diperoleh dari data dokumentasi dengan data yang diperoleh dari wawancara. Selanjutnya, melakukan interpretasi data. ${ }^{7}$ Kemudian, menarik kesimpulan.

\section{Hasil dan Pembahasan}

\section{Statistik Perkara Cerai Gugat di Pengadilan Agama Kelas IA Padang}

Peradilan Agama adalah peradilan bagi orang-orang yang beragama. ${ }^{8}$ Selanjutnya dinyatakan bahwa Peradilan Agama adalah merupakan salah satu pelaksana kekuasaan kehakiman bagi rakyat pencari keadilan yang beragama Islam mengenai perkara tertentu

${ }^{6}$ Lexy J. Moleong, Metodologi Penelitian Kualitatif (Jakarta: Rosda Karya, 2004), h. 288; Koentjaraningrat, Metode-Metode Penelitian Masyarakat (Jakarta; PT. Gramedia, 1981), h. 332.

${ }^{7}$ Moleong, Metodologi Penelitian, h. 247

${ }^{8}$ Pasal 1 Undang-Undang Nomor 3 Tahun 2006 tentang Perubahan Undang-Undang Nomor 7 Tahun 1989 tentang Peradilan Agama. 
yang diatur undang-undang ini. ${ }^{9}$ Ketentuan kedua pasal di atas menunjukkan bahwa subjek hukum yang menjadi kewenangan peradilan agama adalah orang-orang yang beragama Islam. Hal ini dikenal dengan asas personalitas keislaman. ${ }^{10}$

Pelaksanaan kekuasaan kehakiman di Indonesia di lingkungan Peradilan Agama dilaksanakan oleh tiga tingkat pengadilan. Pertama, Pengadilan Agama. Pengadilan Agama merupakan pengadilan tingkat pertama di lingkungan Peradilan Agama. Pengadilan Agama berkedudukan di ibu kota Kabupaten dan Kota di seluruh Indonesia dan wilayah hukumnya meliputi wilayah hukum satu kabupaten atau kota di mana ia berkedudukan. Kedua, Pengadilan Tinggi Agama, yang merupakan pengadilan tingkat banding. Pengadilan Tinggi Agama berkedudukan di setiap ibu kota provinsi dan mempunyai wilayah hukum meliputi seluruh wilayah hukum provinsi tersebut. Ketiga, Badilag (Badan Peradilan Agama) Mahkamah Agung, yang berkedudukan di Jakarta sebagai ibukota negara Indonesia dan wilayah hukumnya meliputi seluruh wilayah Indonesia. Pengadilan Agama Kelas I A Padang adalah salah satu pengadilan tingkat pertama di lingkungan Pengadilan Tinggi Agama Padang. Ia berkedudukan di Kota Padang dan mempunyai wilayah hukum meliputi wilayah hukum daerah tingkat dua Kota Padang.

Adapun mengenai kewenangan perkara pengadilan agama diatur dalam pasal 49 Undang-Undang Nomor 3 Tahun 2006. Pengadilan Agama bertugas dan berwenang memeriksa, memutus, dan menyelesaikan perkara-perkara di tingkat pertama antara orang-orang yang beragama Islam di bidang: (a). Perkawinan, (b). Kewarisan (c) wasiat (d) hibah (e) wakaf (f) zakat (g) infak (h) shadaqah dan (i) ekonomi syari'ah. Salah satu perkara yang menjadi kewenangan pengadilan agama adalah bidang perkawinan umat Islam. Sesuai dengan penjelasan pasal 49 Undang-Undang Nomor 3 Tahun 2006, kewenangan perkawinan ini meliputi 22 macam kewenangan sebagaimana diatur oleh Undang-Undang Perkawinan. Di antara kewenangan pengadilan agama di bidang perkawinan adalah perceraian karena talak dan gugatan perceraian. Perkara perceraian karena talak adalah perkara perceraian yang diajukan oleh suami. Sebaliknya perkara gugatan cerai adalah perkara perceraian yang diajukan oleh istri.

Jumlah perkara yang diajukan dan diselesaikan oleh sebuah pengadilan dipengaruhi oleh beberapa hal. Di antara faktor yang mempengaruhinya adalah kewenangan pengadilan terhadap suatu perkara dan wilayah hukum yang dimilikinya. Keberadaan peraturan perundangundangan yang mengaturnya juga sangat memengaruhinya. Apakah ada aturan yang jelas yang mengaturnya, dan apakah aturan itu tersosialisasi kepada masyarakat.

Lembaga pengadilan sebagai lembaga yang melaksanakan tugas penyelesaian perkara

${ }^{9}$ Pasal 2 Undang-Undang Nomor 3 Tahun 2006 tentang Perubahan Undang-Undang Nomor 7 Tahun 1989 tentang Peradilan Agama.

${ }^{10}$ Asasriwarni dan Nurhasanah, Peradilan Agama di Indonesia (Padang: Hayfa Press, 2006), h. 7 
tersebut juga sangat berpengaruh terhadap perkara yang diajukan dan diselesaikannya. Pelayanan lembaga pengadilan yang baik dan didukung dengan keberadaan pejabat pelaksana kekuasaan kehakiman di pengadilan (terutama hakim, panitera dan jurusita) serta sarana dan prasarana yang memberikan kemudahan dan kenyaman terhadap para pihak yang akan berperkara, juga akan memengaruhi para pihak untuk mengajukan perkaranya ke pengadilan.

Jumlah perkara perceraian yang diajukan ke Pengadilan Agama Kelas I A Padang terus meningkat dari tahun ke tahun. Pada tahun 2008 angka perkara perceraian berjumlah 771 perkara yang terdiri dari 261 perkara permohonan cerai (38\%) dan gugatan cerai sebanyak 424 perkara (62\%). Pada tahun ini jumlah persentase angka perkara gugatan cerai jauh lebih tinggi dari angka permohonan cerai. Dua tahun berikutnya angka perceraian meningkat dari tahun sebelumnya dan angka gugatan cerai juga lebih tinggi dari angka permohonan cerai. Pada tahun 2009, perkara permohonan cerai berjumlah 728 perkara yang terdiri dari 246 permohonan cerai (35\%) dan gugatan cerai berjumlah sebanyak 462 perkara (65\%). Sedangkan pada tahun 2010, perceraian yang duajukan ke Pengadilan Agama Padang adalah sebanyak 851 perkara yang terdiri dari 278 permohonan cerai (33\%) dan 573 perkara gugatan cerai (67\%). Pada tahun berikutnya, yaitu tahun 2011, perkara perceraian juga semakin meningkat. Dari semua perkara perceraian yang diselesaikan oleh Pengadilan Agama Padang tersebut, jumlah dan persentase angka gugatan cerai juga sangat jauh melebihi angka perkara permohonan cerai. Pada tahun 2011 ini perkara perceraian berjumlah 851 perkara, yang terdiri dari 325 perkara permohonan cerai (35\%) dan 615 perkara gugatan cerai (65\%). Dari semua perkara perceraian yang diselesaikan oleh Pengadilan Agama Kelas I A Padang angka cerai gugat jauh lebih banyak dibandingkan dengan permohonan cerai. Tahun 2012 jumlah perkara gugatan cerai berjumlah 688 (65\%), sementara perkara permohonan cerai berjumlah 354 (34\%) dari jumlah perkara yang masuk (1042). Hal tersebut dapat dijelaskan pada tabel di bawah ini:

Tabel 2.

Perkembangan Perkara Perceraian

\begin{tabular}{|c|c|c|c|c|c|}
\hline Tahun & Jumlah Perkara & \multicolumn{2}{|c|}{ Permohonan Cerai } & \multicolumn{2}{|c|}{ Gugatan Cerai } \\
\hline 2008 & 771 & 261 & $38 \%$ & 424 & $62 \%$ \\
\hline 2009 & 728 & 246 & $35 \%$ & 462 & $65 \%$ \\
\hline 2010 & 851 & 278 & $33 \%$ & 573 & $67 \%$ \\
\hline 2011 & 851 & 328 & $35 \%$ & 615 & $65 \%$ \\
\hline 2012 & 1042 & 354 & $34 \%$ & 688 & $66 \%$ \\
\hline Total & 3702 & 1298 & $35 \%$ & 2390 & $65 \%$ \\
\hline
\end{tabular}

Sumber: Laporan Tahunan Pengadilan Agama Kelas I A Padang, tahun 2008-2012

Selanjutnya, dilihat dari segi usia para pihak yang mengajukan perkara perceraian 
di Pengadilan Agama Kelas I A Padang, terlihat bahwa perceraian terjadi pada berbagai usia. Perceraian pada usia 16-20 tahun tidak banyak terjadi. Hal ini disebabkan karena perkawinan pada usia tersebut juga tidak banyak lagi dilakukan masyarakat Kota Padang, sehingga angka perceraian pada usia ini juga tidak banyak terjadi.

Usia terbanyak yang mengajukan perceraian adalah suami isteri yang berusia di antara 21-40 tahun. Hal ini menunjukkan bahwa pada usia ini perceraian lebih cenderung terjadi. Bila dilihat dari produktivitas, maka usia ini merupakan usia yang paling produktif dalam kehidupan manusia. Pada usia ini, selain merupakan usia yang paling produktif, usia ini merupakan masa yang paling rawan dalam kehidupan sebuah rumah tangga. Pada masa ini suami isteri akan dihadapkan pada berbagai tuntutan hidup dalam membangun keluarganya, kondisi kehidupan yang tidak mudah dan cenderung menimbulkan konflik bila tidak pandai menghadapinya.

Di bawah itu, perceraian juga banyak terjadi pada usia 41-60 tahun. Perceraian pada paling sedikit terjadi pada usia 61 tahun ke atas. Hal ini karena pada usia tersebut kehidupan keluarga sudah cenderung berjalan dengan stabil. Tuntutan kehidupan keluarga tidak lagi sebanyak pada usia sebelumnya. Suami isteri sudah banyak yang menjalani kehidupan yang mapan secara materi dan stabil dari segi emosi. Di antara suami isteri tidak lagi banyak menghadapi konflik atau sudah jauh lebih mampu menangani masalah kehidupan rumah tangga.

Selanjutnya statisitik perceraian di Pengadilan Agama Kelas IA Padang dapat dilihat dari pekerjaan para pihak. Pekerjaan para pihak yang mengajukan perkara perceraian ke Pengadilan Agama Kelas I A Padang diklasifikasi menjadi:

Pertama, PNS/TNI/POLRI, yaitu pekerjaan sebagai pegawai pemerintah dan hidup dengan kondisi yang lebih terjamin dengan penghasilan yang cenderung tetap dan stabil. Kelompok ini merupakan yang paling sedikit bercerai dibandingkan dengan dua kelompok lainnya. Kedua, para pihak yang terdiri dari swasta dan buruh. Para pihak dari kelompok pekerjaan ini lebih cendrung banyak mengahadapi konflik dari perkawinan mereka. Mereka cendrung menghadapi banyak masalah dalam pekerjaan mereka. Pekerjaan dan penghasilan yang tidak terjamin dan tidak tetap sebagaimana halnya PNS/TNI/POLRI. Ketiga, kelompok yang tidak mempunyai pekerjaan. Kelompok ini paling sedikit mengajukan perceraian. Hal ini disebabkan karena para pihak yang benar-benar tidak memiliki pekerjaan sama sekali tidak banyak di dalam masyarakat.

Menurut data dari Pengadilan Agama Kelas I A Padang ada beberapa hal yang menjadi faktor penyebab terjadinya perkara perceraian di Pengadilan Agama Kelas I A Padang. Faktor penyebabnya adalah poligami tidak sehat, krisis akhlak, cemburu, ekonomi, tidak ada tanggung jawab, kawin di bawah umur, dihukum, cacat biologis, Kekerasan Dalam Rumah Tangga (KDRT), gangguan pihak ketiga, tidak ada keharmonisan, penganiayaan dan kekejaman mental. Untuk lebih jelasnya digambarkan pada tabel di bawah ini: 
MIQOT Vol. XXXVIII No. 2 Juli-Desember 2014

Tabel 6.

Penyebab Perceraian

\begin{tabular}{|c|l|c|c|c|c|c|}
\hline No & \multicolumn{1}{|c|}{ Jenis Perkara } & $\mathbf{2 0 0 9}$ & $\mathbf{2 0 1 0}$ & $\mathbf{2 0 1 1}$ & $\mathbf{2 0 1 2}$ & Total \\
\hline 1 & Poligami tidak sehat & & 2 & & 4 & 6 \\
\hline 2 & Krisis akhlak & & & 8 & & 8 \\
\hline 3 & Cemburu & & & 22 & 68 & 90 \\
\hline 4 & Ekonomi & 5 & & 72 & 126 & 203 \\
\hline 5 & Tidak bertanggungjawab & 200 & 603 & 289 & 468 & 1560 \\
\hline 6 & Kawin di bawah umur & & & & & 0 \\
\hline 7 & Dihukum & & 2 & & & 2 \\
\hline 8 & Cacat biologis & & 2 & & & 2 \\
\hline 9 & KDRT & 1 & 1 & 5 & & 7 \\
\hline 10 & Gangguana pihak ketiga & & & 18 & 76 & 94 \\
\hline 11 & Tidak ada keharmonisan & 200 & 201 & 222 & 304 & 927 \\
\hline
\end{tabular}

Sumber: Pengadilan Agama Kelas I A Padang, Tahun 2013

Berdasarkan data penyebab terjadinya perceraian di Pengadilan Agama Kelas I A Padang di atas dapat dijelaskan sebagai berikut.

1. Poligami yang tidak sehat

Hal ini dapat dilihat dari beberapa perkara seperti tergugat telah menikah lagi dengan wanita lain dan telah mempunyai seorang anak. ${ }^{11}$ Tergugat tidak jujur kepada penggugat, yang mana pada waktu pernikahan dulu tergugat menyatakan kepada penggugat bahwa tergugat masih sendiri, ternyata tergugat sudah punya isteri dan anak. ${ }^{12}$

2. Krisis Akhlak

Suka berjudi, minum-minuman keras dan kecanduan narkoba, suka berbohong dan lain-lain.

3. Cemburu

Hal ini dapat dilihat dari beberapa perkara seperti tergugat suka cemburu dan tidak percaya terhadap pasangannya. ${ }^{13}$

4. Ekonomi

Hal ini dapat dilihat dari perkara seperti tergugat memberikan belanja rumah tangga

${ }^{11}$ Salinan Putusan Pengadilan Agama Padang Nomor: 257/Pdt.G/2009/PA.Pdg. Lihat juga perkara Salinan Putusan Pengadilan Agama Padang Nomor: 117/Pdt.G/2009/PA.Pdg.

${ }^{12}$ Salinan Putusan Pengadilan Agama Padang Nomor: 418/Pdt.G/2009/PA.Pdg.

${ }^{13}$ Salinan Putusan Pengadilan Agama Padang Nomor: 244/Pdt.G/2009/PA.Pdg. 
tidak pernah cukup, sehingga untuk memenuhi kebutuhan rumah tangga penggugat dibantu oleh orang tua tergugat; ${ }^{14}$ Tergugat tidak jujur dalam masalah keuangan. ${ }^{15}$

5. Tidak ada tanggung jawab

Masalah tidak adanya tanggung jawab menjadi penyebab perceraian yang sangat mendominasi di Pengadilan Agama Kelas I A Padang. Keadaan ini pada umumnya dipicu oleh masalah ekonomi. Tergugat memberikan nafkah tidak pernah mencukupi untuk kebutuhan rumah tangga karena tergugat lebih mendahulukan memenuhi kebutuhan orang tuanya daripada memenuhi kebutuhan anak dan penggugat, sehingga kebutuhan rumah tangga setiap hari selalu dipenuhi oleh penggugat. ${ }^{16}$ Pada perkara lain juga terungkap tergugat tidak pernah memberi nafkah wajib kepada peng-gugat. ${ }^{17}$ Antara penggugat dan tergugat telah pisah selama 4 tahun namun, hanya 3 kali memberikan nafkah wajib, tidak mencukupi dan tergugat tidak mempedulikan penggugat sama sekali. ${ }^{18}$ Untuk memenuhi kebutuhan rumah tangga penggugat berusaha sendiri dibantu orang tua penggugat. Sementara uang hasil usaha penggugat habis tidak menentu oleh tergugat, akibatnya penggugat kehabisan modal untuk jualan, sehingga penggugat saat ini tidak bisa berjualan lagi. ${ }^{19}$ Tergugat jarang pulang ke tempat kediaman bersama; tergugat tidak melaksanakan kewajibannya sebagai suami, sejak berpisah tergugat tidak pernah mengirimkan nafkah wajib kepada penggugat. ${ }^{20}$

6. Kekerasan Dalam Rumah Tangga (KDRT)

Hal ini dapat dilihat dari perkara seperti tergugat meninju dan menendang penggugat. Tergugat pernah mengancam dengan pisau dan memukul tangan penggugat dengan batang tebu yang mengakibatkan tangan penggugat membiru ${ }^{21}$ Tergugat sering melakukan kekasaran dalam rumah tangga baik kepada penggugat maupun anak-anak. Tergugat dalam mendidik anak tidak pernah mau berkata dengan baik, selalu menghardik dan berkata kasar. Jika dinasehati sebaliknya penggugat yang dihardik dan dikasari ${ }^{22}$ Tergugat tidak menghargai penggugat sebagai istri dan ibu bagi anak-anak, sering menghina, memandang penggugat sebagai orang yang bodoh, selalu berburuk sangka dan tidak

${ }^{14}$ Salinan Putusan Pengadilan Agama Padang Nomor: 309/Pdt.G/2009/PA.Pdg. Lihat juga Salinan Putusan Pengadilan Agama Padang Nomor: 418/Pdt.G/2009/PA.Pdg.

${ }^{15}$ Salinan Putusan Pengadilan Agama Padang Nomor: 682/Pdt.G/2008/PA.Pdg.

${ }^{16}$ Salinan Putusan Pengadilan Agama Padang: 244/Pdt.G/2009/PA.Pdg. Lihat juga Salinan Putusan Pengadilan Agama Padang Nomor: 682/Pdt.G/2008/PA.Pdg.

${ }^{17}$ Salinan Putusan Pengadilan Agama Padang Nomor: 257/Pdt.G/2009/PA.Pdg. Lihat juga Salinan Putusan Pengadilan Agama Padang Nomor: 303/Pdt.G/2010/PA.Pdg.

${ }^{18}$ Salinan Putusan Pengadilan Agama Padang Nomor: 117/Pdt.G/2009/PA.Pdg.

${ }^{19}$ Salinan Putusan Pengadilan Agama Padang Nomor: 418/Pdt.G/2009/PA.Pdg. Lihat juga Salinan Putusan Pengadilan Agama Padang Nomor: 1023/Pdt.G/2012/PA.Pdg.

${ }^{20}$ Salinan Putusan Pengadilan Agama Padang Nomor: 01/Pdt.G/2010/PA.Pdg.

${ }^{21}$ Salinan Putusan Pengadilan Agama Padang Nomor: 309/Pdt.G/2009/PA.Pdg. Lihat juga Salinan Putusan Pengadilan Agama Padang Nomor: 309/Pdt.G/2009/PA.Pdg.

${ }^{22}$ Salinan Putusan Pengadilan Agama Padang Nomor: 303/Pdt.G/2010/PA.Pdg. 
membolehkan penggugat bersosialisasi dengan orang lain, serta tidak pernah berkata dengan baik kepada penggugat. ${ }^{23}$ Tergugat sering mengatakan kepada anak-anak bahwa penggugat adalah orang yang bodoh dan tidak bisa mengurus rumah tangga. Tergugat sering mengusir penggugat dari rumah kediaman bersama. ${ }^{24}$

7. Gangguan pihak ketiga

Hal ini dapat dilihat dari perkara di mana keluarga tergugat ikut campur terhadap urusan rumah tangga penggugat dengan tergugat. ${ }^{25}$ Adanya ikut campur pihak ketiga (orang tua tergugat) yang selalu merongrong tergugat memenuhi kebutuhan mereka. Orang tua tergugat terlalu banyak menyinggung perasaan penggugat ${ }^{26}$.

8. Tidak ada keharmonisan

Tidak adanya keharmonisan dalam rumah tangga juga termasuk penyebab perceraian yang dominan diajukan di Pengadilan Agama Kelas I A Padang. Hal ini dapat dilihat dari seringnya terjadi perselisihan dan pertengkaran antara penggugat dan tergugat. Tergugat bersikap kasar kepada penggugat dan mengucapkan talak 3 kepada penggugat. ${ }^{27}$ Rumah tangga penggugat dengan tergugat tidak berjalan rukun dan harmonis, karena sering terjadi perselisihan dan pertengkaran. ${ }^{28}$ Pada perkara lain juga terungkap sering terjadi pertengkaran antara penggugat dengan tergugat. Sejak itu tergugat pergi dari tempat kediaman bersama, antara penggugat dengan tergugat telah pisah selama 12 tahun 4 bulan, tergugat tidak pernah datang lagi dan tidak ada kabar berita. ${ }^{29}$ Penggugat dan tergugat tidak pernah lagi berkomunikasi dengan baik, tidak lagi melakukan hubungan suami istri, dan sudah lebih dari 1 tahun pisah ranjang. ${ }^{30}$ Sejak awal pernikahan rumah tangga penggugat dengan tergugat sudah goyah. Antara penggugat dan tergugat sering terjadi perselisihan yang disebabkan karena keluarga penggugat dengan tergugat berselisih paham tentang pelaksanaan pesta pernikahan. ${ }^{31}$

\section{Faktor Meningkatnya Angka Gugatan Cerai di Pengadilan Agama Kelas I A Padang}

Faktor penyebab meningkatnya angka gugatan cerai di Pengadilan Agama Kelas I A Padang dapat diklasifikasi ke dalam beberapa aspek, yakni:

${ }^{23}$ Salinan Putusan Pengadilan Agama Padang Nomor: 303/Pdt.G/2010/PA.Pdg.

${ }^{24}$ Salinan Putusan Pengadilan Agama Padang Nomor: 303/Pdt.G/2010/PA.Pdg.

${ }^{25}$ Salinan Putusan Pengadilan Agama Padang Nomor: 418/Pdt.G/2009/PA.Pdg. Lihat juga Salinan Putusan Pengadilan Agama Padang Nomor: 682/Pdt.G/2008/PA.Pdg.

${ }^{26}$ Salinan Putusan Pengadilan Agama Padang Nomor: 1037/Pdt.G/2012/PA.Pdg.

${ }^{27}$ Salinan Putusan Pengadilan Agama Padang Nomor: 257/Pdt.G/2009/PA.Pdg.

${ }^{28}$ Salinan Putusan Pengadilan Agama Padang Nomor: 309/Pdt.G/2009/PA.Pdg.

${ }^{29}$ Salinan Putusan Pengadilan Agama Padang Nomor: 682/Pdt.G/2008/PA.Pdg. Lihat juga Salinan Putusan Pengadilan Agama Padang Nomor: 01/Pdt.G/2010/PA.Pdg.

${ }^{30}$ Salinan Putusan Pengadilan Agama Padang Nomor: 303/Pdt.G/2010/PA.Pdg.

${ }^{31}$ Salinan Putusan Pengadilan Agama Padang Nomor: 1037/Pdt.G/2012/PA.Pdg. 


\section{Aspek Spritual dan Emosional}

Berdasarkan perkara yang mendominasi gugatan perceraian di Pengadilan Agama Kelas I A Padang aspek ini merupakan faktor utama terjadinya gugatan cerai. Aspek-aspek ini dapat dijelaskan sebagai berikut. Pertama,Semakin tingginya masalah atau konflik yang terjadi dalam kehidupan keluarga. Pada saat ini masalah yang dihadapi sebuah keluarga semakin tinggi. Kondisi ekonomi yang kurang kondusif berhadapan dengan tingginya kebutuhan hidup. Persoalan-persoalan di luar lingkungan keluarga juga turut memicu munculnya masalah dan konflik dalam keluarga. Ketika terjadi masalah dalam keluarga, isteri adalah pihak yang lebih banyak tahu, merasakan dan menghadapi kondisi-kondisi tersebut. Oleh karena itu, perempuan lebih banyak berinisiatif mengajukan gugatan cerai karena ketika terjadi konflik, karena perempuan lebih merasakan dampak dari konflik tersebut. Laki-laki biasanya santai menghadapinya. Ia bisa keluar rumah, baik sementara atau dalam jangka waktu yang lama. Perempuan tidak mungkin melakukan hal itu, karena hal tersebut akan dipandang negatif oleh masyarakat. ${ }^{32}$ Sehingga ketika perempuan ingin lepas dari kondisi tersebut ia mengambil keputusan untuk bercerai. Misalnya suami tidak mampu memenuhi kebutuhan keluarga, atau suami hanya memberikan seadanya kepada isteri. Sementara, isteri tidak bisa menerima keadaan ini sehingga isteri memutuskan untuk mengajukan gugatan cerai.

Kedua, Semakin rendahnya keimanan, akhlak, pengetahuan, pemahaman dan pengamalan nilai-nilai agama dalam kehidupan keluarga. Kehidupan rumah tangga harus dilandasi oleh iman dan akhlakul karimah. Menipisnya iman dan akhlak di kalangan anggota keluarga akan menyebabkan hancurnya keluarga tersebut. Fenomena ini terlihat dalam kehidupan keluarga saat ini. Banyaknya konflik yang terjadi di dalam keluarga yang memicu banyaknya perempuan mengajukan gugatan cerai menunjukkan menipisnya iman dan akhlak dalam kehidupan keluarga. ${ }^{33} \mathrm{Hal}$ ini juga dijelaskan Ulfatmi, menipisnya pengamalan nilai-nilai agama di kalangan perempuan terlihat dari perubahan profil perempuan sekarang dibandingkan dengan perempuan dulu. Perempuan dulu mempunyai keikhlasan dan kesabaran yang besar. Motivasi mereka dalam melaksanakan tugas sebagai isteri dan ibu adalah ibadah, sehingga mereka lebih ikhlas dan sabar. Mental perempuan dulu kuat dan tidak mudah lelah, mereka memiliki semangat serta ketangguhan dalam menghadapi sikap dan kelemahan suami. Hal ini menyebabkan mereka cenderung bertahan menghadapi masalah rumah tangganya dan memilih untuk tidak bercerai dari suaminya ketika berhadapan dengan masalah antara dia dan suaminya. Namun, karakter tersebut telah menipis di

\footnotetext{
${ }^{32}$ Wawancara dengan Ahmad Anshary, Hakim Pengadilan Agama Padang, Padang, 18 September 2013.

${ }^{33}$ Wawancara dengan Ahmad Anshary, Hakim Pengadilan Agama Padang, Padang, 18 September 2013.
} 
kalangan perempuan sekarang. ${ }^{34}$ Sehingga muncullah fenomena banyaknya perempuan mengajajukan gugatan cerai. ${ }^{35}$

Ketiga, Menurunnya ketahanan dan kesabaran perempuan menghadapi konflik yang terjadi dalam rumah tangga. Kurang sabarnya perempuan menghadapi masalah dalam rumah tangga membuat mereka cenderung lebih cepat memutuskan untuk bercerai dengan suaminya. Banyak di antara perempuan mengajukan gugatan cerai karena konflik keluarga, padahal konflik tersebut baru saja terjadi dua tahun belakangan. ${ }^{36}$ Malahan, ada perkara gugatan cerai yang diajukan isteri setelah 3 bulan menikah yang dipicu oleh perselisihan di antara orang tua kedua belah pihak. ${ }^{37}$

\section{Aspek Ekonomi}

Masalah ekonomi, menjadi penyebab konflik yang berkepanjangan dalam rumah tangga karena isteri mengaangap suami kurang bertanggung jawab dalam pemenuhan kebutuhan rumah tangga. Di antara faktor pemicu ini adalah. Pertama, semakin tingginya tuntutan kebutuhan rumah tangga. Meningkatnya angka gugatan cerai di antaranya disebabkan oleh karena terjadinya perubahan tuntutan hidup berkeluarga. Dulu tuntutan hidup berkeluarga tidak besar, sedangkan sekarang sangat besar ${ }^{38}$ Kondisi ini diperparah oleh adanya gaya hidup konsumerisme di kalangan perempuan. Menurut Zualis Saleh Hakim Pengadilan Agama Kelas I A Padang. Tingginya sikap konsumtif di kalangan perempuan merupakan salah satu penyebab tingginya angka gugatan cerai. Ketika tuntutan isteri tidak terpenuhi oleh suami, seringkali menimbulkan konflik di antara suami isteri yang pada akhirnya bisa menyebabkan isteri meminta cerai dari suaminya. ${ }^{39}$

Kedua, wanita berkarier dan memiliki penghasilan sendiri. Menurut Ulfatmi Konsultan Keluarga Sakinah, banyaknya perempuan bekerja atau berkarir di luar rumah juga merupakan salah satu faktor yang menyebabkan tingginya angka perceraian. Perempuan bekerja merupakan salah satu penyebab timbulnya konflik antara suami isteri. Bila isteri bekerja kemudian ia mengabaikan hak-hak suaminya adalah pemicu terjadinya perselisihan suami istri. Ketika suami merasa hak-haknya diabaikan sering menyebabkan terjadi ketidakharmonisan antara suami isteri. Bahkan berakibat terjadinya perselingkuhan.

\footnotetext{
${ }^{34}$ Wawancara dengan Ulfatmi, Pakar Konsultan Rumah Tangga Sakinah Provinsi Sumatera Barat, Padang, 23 September 2013.

${ }^{35}$ Wawancara dengan Zuarlis Saleh, Hakim Pengadilan Agama Padang, Padang, 18 September 2013.

${ }^{36}$ Wawancara dengan Zainal, Hakim Pengadilan Agama Padang, Padang, 19 September 2013.

${ }^{37}$ Salinan Putusan Pengadilan Agama Padang Nomor: 1037/ Pdt.G/ 2012/PA Pdg.

${ }^{38}$ Wawancara dengan Ulfatmi, Pakar Konsultan Rumah Tangga Sakinah Sumatera Barat, Padang, 23 September 2013.

${ }^{39}$ Wawancara dengan Zuarlis Saleh, Hakim Pengadilan Agama Padang, Padang, 18 September 2013.
} 
Hal ini menyebabkan terjadinya ketidakharmonisan antara suami isteri, pada akhirnya menyebabkan konflik suami istri yang berujung pada perceraian. ${ }^{40} \mathrm{Di}$ samping itu, istri yang bekerja seringkali mempunyai tugas yang amat berat karena harus melaksanakan tugas ganda, yaitu sebagai isteri, ibu serta tugas sebagai perempuan bekerja. Pelaksanaan tugas-tugas tersebut seringkali menyebabkan terabaikannya hak-hak suami. Kondisi ini sering juga tidak dipahami dan dimengerti oleh suami, sehingga muncullah konflik antara suami istri karena suami menganggap hak-haknya terabaikan. Pada sisi yang lain, istri yang bekerja dan memiliki penghasilan sendiri cenderung tidak takut menggugat cerai suaminya. Karena ia tidak tergantung sepenuhnya kepada suaminya secara ekonomi. Bahkan, banyak terjadi penghasilan istri lebih tinggi daripada penghasilan suaminya. Keadaan ini juga menjadi salah satu faktor penyebab meningkatnya angka gugatan cerai di Pengadilan Agama Kelas I A Padang. Menurut Siti Raudhah Thaib Ketua Bundo Kanduang, hal ini bisa menyebabkan kurangnya penghargaan isteri terhadap suami. Padahal sebagai laki-laki dan suami, bagaimanapun kondisinya tetap ingin dihargai oleh isterinya. ${ }^{41}$

\section{Tingkat Pendidikan}

Zaman sekarang, perempuan sudah mendapatkan pendidikan yang relatif tinggi. Kaum perempuan sudah banyak yang cerdas, sadar hukum dan berani memperjuangkan hak-haknya. Berdasarkan data di Pengadilan Agama Kelas I A Padang pendidikan tidak menjadi faktor penyebab utama perempuan mengajukan gugatan cerai. Karena gugatan cerai diajukan oleh perempuan dari semua tingkat pendidikan, baik pendidikan dasar, menengah maupun pendidikan tinggi. ${ }^{42}$ Namun, meningkatnya pendidikan perempuan memberi pengaruh yang kuat terhadap kesadaran hukum perempuan. Keadaan ini dapat dilihat pada beberapa aspek, yakni:

Pertama, semakin tingginya tingkat pendidikan perempuan. Meningkatnya tingkat pendidikan perempuan menyebabkan perempuan semakin pintar dan cerdas, sehingga ia semakin sadar akan hukum, semakin sadar akan hak-haknya dalam keluarga serta punya kemauan dan keberanian untuk memperjuangkan hak-haknya. Ketika terjadi masalah antara suami istri, di mana istri merasa tertekan dan menderita dengan kondisi itu, ia tidak mau membiarkan dirinya berlarut-larut dalam kondisi itu. Ia akan mencari solusi untuk menyelesaikan masalah tersebut. Kemudian, ia memutuskan untuk bercerai bila menganggap perceraian adalah jalan keluarnya. Bila suami tidak mengambil inisiatif untuk bercerai, maka ia yang akan mengambil keputusan sendiri. Dari fenomena yang

\footnotetext{
${ }^{40}$ Wawancara dengan Ulfatmi, Pakar Konsultan Rumah Tangga Sakinah Sumatera Barat, Padang, 23 September 2013.

${ }^{41}$ Wawancara dengan Raudhah Thaib, Ketua Bundo Kanduang Sumatera Barat, Padang, 27 September 2013.

${ }^{42}$ Wawancara dengan Yelti Multi, Panitera Muda Hukum Pengadilan Agama Kelas IA Padang, Padang, 25 Mei 2012.
} 
terjadi di Kota Padang, ternyata inisiatif bercerai lebih banyak diambil oleh perempuan, sehingga angka gugatan cerai lebih banyak jika dibandingkan angka permohonan cerai.

Kedua, meningkatnya kesadaran hukum perempuan dan meningkatnya keberanian perempuan memperjuangkan hak-haknya. Meningkatnya angka gugatan cerai menurut Ahmad Anshari, Hakim Pengadilan Agama Kelas I A Padang, mengindikasikan bahwa perempuan sekarang memiliki kesadaran hukum yang tinggi. Ketika terjadi masalah rumah tangga perempuan mau berkonsultasi dengan orang-orang yang mengerti hukum dan berani memperjuangkan hak-haknya. ${ }^{43}$ Hal ini juga dikemukan oleh Panitera Muda Gugatan Pengadilan Agama Kelas I A Padang bahwa meningkatnya gugatan cerai dipengaruhi oleh pengetahuan perempuan itu sudah tahu ke mana ia akan menyelesaian masalahnya ketika terjadi konflik rumah tangga. Ia sudah tahu hak-haknya. ${ }^{44}$ Ini berarti kesadaran hukum perempuan sudah meningkat.

\section{Aspek Perubahan Sosial}

Perubahan budaya membawa pengaruh terhadap persepsi perempuan tentang pernikahan dan perceraian, meliputi, pertama, terjadinya salahpenafsiran kesetaraan gender di kalangan perempuan. Menurut Siti Raudhah Thaib, di kalangan perempuan saat ini terjadi salahpenafsiran terhadap kesetaraan gender. Perempuan menganggap kesetaraan gender itu adalah semua sama. Hal ini menimbulkan ketidakikhlasan perempuan dalam menjalani kehidupan rumah tangga. ${ }^{45} \mathrm{Kedua}$, melemahnya struktur kekerabatan dalam masyarakat Minangkabau. Peran keluarga besar saat ini jauh berkurang terhadap keluarga kecil. Segala persoalan keluarga dihadapi dan diselesaikan sendiri oleh suami istri. Orang tua dan mamak (saudara laki-laki ibu) ${ }^{46}$ seringkali tidak dibawa serta menyelesaikan masalah suami istri. Menurut Yunedi, Panitera Muda Gugatan Pengadilan Agama Kelas I A Padang kurang dilibatkannya keluarga besar dalam menyelesaikan masalah-masalah yang dihadapi suami istri juga cenderung membuat perempuan lebih cepat mengambil keputusan bercerai. ${ }^{47}$ Banyak perempuan yang mengajukan gugatan cerai kesulitan membawa saksi keluarga di persidangan. Ada orang tua yang mengaku bahwa ia baru tahu masalah anaknya ketika anaknya sudah mengajukan perkaranya

${ }^{43}$ Wawancara dengan Ahmad Anshary, Hakim Pengadilan Agama Padang, Padang, 18 September 2013.

${ }^{44}$ Wawancara dengan Yunedi, Panitera Muda Gugatan Pengadilan Agama Padang, Padang, 24 September 2013.

${ }^{45}$ Wawancara dengan Siti Raudhah Thaib, Ketua Bundo Kanduang Sumatera Barat, Padang, 27 September 2013.

${ }^{46}$ Dalam struktur masyarakat Minangkabau, mamak mempunyai peranan yang sangat penting, mamak adalah pimpinan keluarga yang memegang kendali terhadap kemenakannya, ia membimbing, mengasuh, dan memimpin kemenakan secara materil dan spirituil.

${ }^{47}$ Wawancara dengan Yunedi, Panitera Muda Gugatan Pengadilan Agama Padang, Padang, 24 September 2013. 
ke Pengadilan Agama. Ketiga, perempuan menutup diri dan berpandangan sempit terhadap poligami dengan bersikap tidak mau dipoligami. Kaum perempuan tidak bisa menerima jika suaminya berpoligami. Poligami ini juga merupakan satu penyebab meningkatnya angka gugatan cerai. Ada pemahaman yang salah di kalangan perempuan sekarang tentang poligami. Perempuan tidak bisa lagi menerima poligami, bahkan ada yang menganggap poligami itu sesuatu yang salah. Sebenarnya peraturan perundang-undangan membolehkan poligami dengan persyaratan tertentu. Peraturan perundang-undangan hanya mempersulit terjadinya poligami dengan adanya aturan-aturan yang harus dipatuhi oleh suami yang akan berpoligami. ${ }^{48}$ Ketika suami ingin berpoligami, isteri pada umumnya tidak mengizinkan. Daripada dimadu, perempuan lebih memilih untuk bercerai. Seperti kasus yang dialami salah seorang perempuan yang bercerai. Ia adalah seorang PNS. Suaminya juga PNS yang bertugas di daerah yang berbeda. Selama enam tahun rumah tangganya berjalan tanpa ada masalah. Namun, tanpa ia ketahui suaminya pulang ke rumah orang tuanya dan membawa istri keduanya beserta seorang anak. Ia tidak menerima dipoligami oleh suaminya sehingga terjadi pertikaian di antara mereka. Keduanya tidak pernah berkomunikasi lagi. Suaminya tidak pernah pulang dan memberi nafkah selama empat tahun. Akhirnya, ia memutuskan untuk mengajukan gugatan cerai ke Pengadilan Agama Kelas I A Padang. ${ }^{49}$

Keempat, terjadinya perubahan persepsi masyarakat terhadap perceraian. Dulu perempuan berpandangan bahwa bercerai apalagi minta cerai dari suami adalah suatu hal yang memalukan. Bercerai adalah hal yang menakutkan serta bercerai adalah hak laki-laki. Masyarakat juga memandang negatif terhadap perempuan yang bercerai. Sekarang persepsi perempuan dan masyarakat terhadap perceraian sudah berubah. Perempuan sekarang memiliki persepsi bahwa bercerai bukan hal yang memalukan bila ada alasan yang jelas. Masyarakat juga tidak lagi memandang negatif perempuan yang bercerai. Perempuan berhak meminta cerai sebagaimana ditentukan hukum. Di samping itu, perempuan juga tidak takut lagi mengajukan cerai ke pengadilan. Hal ini juga sebagaimana dikemukakan oleh Siti Raudhah Thaib, perceraian bagi perempuan saat ini tidak lagi dipandang suatu hal yang memalukan dan tabu dalam masyarakat Minang. Saat ini rasa malu sudah menipis dalam kehidupan masyarakat kita. ${ }^{50}$

\section{Persepsi Perempuan di Kota Padang Terhadap Perceraian}

Persepsi adalah sebuah proses di mana seseorang mengorganisasikan dan menafsirkan kesan indera yang diterimanya sehingga memberikan makna pada lingkungannya. ${ }^{51} \mathrm{~J}$. Winardi menyatakan persepsi merupakan proses kognitif di mana seorang individu mem-

${ }^{48}$ Wawancara dengan Zainal, Hakim Pengadilan Agama Padang, Padang, 19 September 2013. ${ }^{49}$ Putusan Nomor: 117/Pdt.G/2009/PA Pdg.

${ }^{50}$ Wawancara dengan Siti Raudhah Thaib, Ketua Bundo Kanduang Sumatera Barat, Padang, 27 September 2013.

${ }^{51}$ Stephen P. Robbins, Organizational Behavour (Prentice-Hall International, 2001), h. 13. 
berikan arti kepada lingkungannya. ${ }^{52}$ Persepsi merupakan stimulus yang diindera oleh individu, diorganisasikan kemudian diinterpretasikan sehingga individu menyadari dan mengerti tentang apa yang diindera. Proses menginterpretasikan stimulus ini biasanya dipengaruhi pula oleh pengalaman dan proses belajar individu.

Pada masa lalu, persepsi perempuan terhadap perceraian adalah bahwa perceraian itu merupakan suatu hal yang tabu dan memalukan. Apalagi bila perceraian itu terjadi atas keinginan istri. Perempuan yang minta cerai dari suaminya dipandang negatif oleh masyarakat Minang. Sehingga perceraian dianggap sesuatu yang tabu dan memalukan di ranah yang kuat dengan falsafah adat basandi syarak, syarak basandi kitabullah. Sebagai masyarakat yang mayoritas memeluk agama Islam, yang mendasari pandangan perempuan terhadap perceraian adalah melalui pemahaman tentang ajaran Islam itu sendiri. Cerai merupakan suatu perbuatan yang sangat dibenci oleh Tuhan. Namun, jika tidak ada alternatif lain sementara cerai merupakan jalan keluar dalam perkawinan yang tidak mungkin lagi dipertahankan. ${ }^{53}$ Oleh karena itu, perempuan tidak mau meminta cerai kepada suaminya meskipun dalam perkawinannya ia mengalami hal-hal yang tidak menyenangkan dari suaminya, seperti merasa tertekan atau dipoligami. Perempuan lebih bersikap mempertahankan keutuhan rumah tangganya.

Di samping itu, perempuan juga takut untuk meminta cerai dari suaminya karena ia tergantung kepada suaminya dari sisi ekonomi dan psikologis. Meskipun pada umumnya dalam tradisi di Minangkabau perempuan juga memiliki penghasilan dari hasil pengelolaan hartanya. Namun, pada umumnya mereka tergantung dari segi nafkah kepada suaminya. Bila perempuan bercerai dari suaminya tentu ia takut mengenai siapa yang akan menanggung nafkah diri dan anak-anaknya. Apalagi dulu sebuah keluarga pada umumnya merupakan keluarga besar yang mempunyai banyak anak. Hal ini menjadi salah satu alasan mengapa perempuan takut meminta cerai kepada suaminya. Bahkan, perceraian lebih banyak terjadi atas kehendak suami dalam bentuk talak. Tidak jarang terjadi suami menjatuhkan talak terhadap istrinya secara semena-mena. Hak bercerai atau talak dianggap merupakan hak preogratif suami. Kondisi inilah yang menginspirasi lahirnya Undang-Undang Nomor 1 Tahun 1974 tentang perkawinan. Undang-undang ini mengatur bahwa perceraian harus dengan disertai adanya alasan-alasan tertentu yang diatur oleh undang-undang.

Pada awalnya perceraian di Pengadilan Agama masih didominasi oleh cerai talak. Namun, beberapa tahun belakangan ini terjadi fenomena yang menarik. Perceraian yang diajukan ke Pengadilan Agama lebih banyak diajukan atas keinginan istri. Bila melihat kenyataan demikian, tentu telah terjadi perubahan persepsi perempuan di Kota Padang terhadap perceraian. Perubahan persepsi masyarakat terhadap perceraian ini juga merupakan

\footnotetext{
${ }^{52}$ J. Winardi, Motivasi dan Pemotivasian dalam Manajemen (Jakarta: PT. Raja Grafindo, 2004), h. 203.

${ }^{53}$ Abdul Aziz Dahlan, (ed.), Ensiklopedi Hukum Islam (Jakarta: Pt Ichtiar Baru Van Houve), h. 1776 .
} 
salah satu faktor penyebab meningkatnya angka gugatan cerai di Pengadilan Agama Kelas I A Padang. Bila persepsi perempuan terhadap perceraian berubah, maka tentu saja hal ini akan menyebabkan meningkatnya angka perceraian. Persepsi perempuan di Kota Padang terhadap perceraian saat ini dapat dijelaskan sebagai berikut:

Pertama, cerai bukan merupakan hal yang tabu dan memalukan. Ketika konflik yang terjadi secara terus menerus di rumah tangga sudah tidak dapat lagi diselesaikan maka keputusan untuk bercerai itu dianggap suatu keputusan yang baik. Salah seorang di antara perempuan yang bercerai memiliki persepsi, untuk apa malu bercerai kalau rumah tangga kita sudah mengalami konflik yang berkepanjangan. Justru pertengkaran yang terjadi berkepanjangan antara suami istri tersebut lebih merupakan hal yang memalukan. ${ }^{54}$

Sebahagian di antara mereka menyatakan bahwa pada awalnya mereka berpendapat bahwa bercerai tersebut merupakan hal yang memalukan. Ketika terjadi konflik dan perasaan tertekan atas sikap dan perlakuan suami, istri lebih memilih bersikap mengalah dan memendam sendiri masalah yang dihadapinya. Ia tidak ingin persoalan rumah tangganya diketahui pihak di luar rumah tangganya. Apalagi ia hidup di lingkungan keluarga besarnya. Ia juga merasa malu untuk bercerai, sehingga ia tidak segera untuk memutuskan untuk bercerai, meskipun sikap tidak adanya saling memahami serta perasaan tertekan atas sikap suaminya tetap terjadi. Ia baru memutuskan untuk bercerai setelah berada di dalam konflik dengan suaminya selama lima belas tahun. ${ }^{55}$

Perempuan yang bercerai menyatakan bahwa mereka tidak merasa malu terhadap masyarakat di lingkungannya karena bercerai, selama perempuan memang tidak salah atau tidak melakukan hal-hal yang salah dalam kehidupan berkeluarga. Bila masyarakat mengetahui permasalahan yang dihadapi perempuan, maka masyarakat biasanya dapat memaklumi mengapa seorang istri atau perempuan menggugat cerai suaminya ke pengadilan.

Justru masyarakat atau keluarga besarnya menyarankan untuk bercerai karena istri berada pada pihak yang dirugikan dan tertekan karena sikap dan perbuatan suami. Seperti yang dialami seorang guru yang menggugat suaminya karena suami tidak bertanggungjawab terhadap pemenuhan kebutuhan keluarga, bahkan suami sering merampas uangnya dan peralatan rumah tangga hanya untuk judi. ${ }^{56}$

Di samping itu, zaman sekarang perempuan dapat menerima perceraian karena sudah umum terjadi dan menyatakan hal itu biasa saja. Stigma negatif mengenai perceraian di dalam masyarakat menjadi hilang dan masyarakat memberikan toleransi umum terhadap perceraian. Dalam perkembangannya dapat dikatakan bahwa masyarakat tidak memandang

\footnotetext{
${ }^{54}$ Wawancara dengan RLA (inisial), Perempuan yang Bercerai, Pendidikan S1 PGTK, Pekerjaan Ibu Rumah Tangga, Padang, 10 September 2013.

${ }^{55}$ Wawancara dengan Asnt (inisial), Perempuan yang Bercerai, Pendidikan SMK, Pekerjaan berjualan, Padang, 10 September 2013.

${ }^{56}$ Wawancara dengan NHYT (inisial), Perempuan yang bercerai, guru, pendidikan SPG, Padang, 25 September 2013.
} 
perceraian sebagai hal yang tabu, artinya perbuatan ini bukan sesuatu yang memalukan dan harus dihindari. Pada tingkat tertentu masyarakat memberikan toleransi umum dan memahami bahwa perceraian adalah salah satu langkah yang harus ditempuh bagi penyelesaian perselisihan suami istri. ${ }^{57}$

Kedua, cerai merupakan solusi untuk menyelesaikan permasalahan atau konflik berkepanjangan yang terjadi di dalam keluarganya. Menurut perempuan yang bercerai, bila masalah yang terjadi dalam jangka waktu yang panjang tidak bisa diselesaikan juga, maka perceraian merupakan solusi untuk menyelesaikannya. Hasil wawancara secara mendalam terhadap informan wanita bercerai, mereka memandang perceraian adalah jalan keluar dari masalah yang berkepanjangan. Hampir semua informan dalam proses kehidupan perkawinan mereka sebelumnya memang tidak luput dari berbagai masalah yang melahirkan konflik dan pertengakaran terus menerus. Mereka sudah sampai pada satu titik di mana tidak dapat lagi mencari jalan keluar yang terbaik. ${ }^{58}$ Perceraian ditempuh untuk maksud keluar dari akumulasi pertengkaran yang terjadi secara terus menerus. Seperti yang diakui oleh seorang perempuan yang bercerai, ia sudah berusaha bertahan dari kemelut rumah tangganya selama 13 tahun baru kemudian memutuskan untuk bercerai. ${ }^{59}$ Ini tentu waktu yang panjang baginya untuk mempertimbangkan pengajuan gugatan cerai ke PA.

Ketiga, cerai bukan sesuatu yang menakutkan. Persepsi ini muncul ketika perempuan yang mengalami konflik rumah tangga memiliki penghasilan sendiri dan merasa sanggup untuk memenuhi kebutuhan diri dan anak-anaknya. Apalagi bila selama ini suami tidak memberikan nafkah yang cukup untuk kebutuhan keluarganya dan isteri ikut bekerja untuk mencukupi kebutuhan keluarganya, istri tidak takut untuk meminta cerai dari suami. Jadi, ketika terjadi konflik yang berkepanjangan dengan suami, istri berpikir lebih baik bercerai dan lepas dari masalah dengan suaminya sehingga dapat lebih tenang mencari nafkah untuk diri dan anak-anaknya. Dengan bercerai, istri tidak lagi merasa terbebani oleh konflik dengan suaminya.

Namun, bila dilihat dari data perkara gugat cerai di Pengadilan Agama Kelas I A Padang cukup banyak perempuan yang bercerai itu berstatus ibu rumah tangga (tidak bekerja) ketika mengajukan gugatan cerai. Pada kenyataannya sebenarnya ia juga mempunyai pengahasilan sendiri. Menurut Zuarlis Saleh hakim Pengadilan Agama Kelas I A Padang, meskipun mereka berstatus ibu rumah tangga, sebenarnya mereka tetap mempunyai penghasilan. ${ }^{60}$

\footnotetext{
${ }^{57}$ Wawancara dengan Desparika Metra, Pengacara Syariah Konsulting, Padang, 24 September 2013.

${ }^{58}$ Wawancara dengan A (inisial), Perempuan yang bercerai, Ibu Rumah Tangga, pendidikan SMA, Padang, 11 September 2013.

${ }^{59}$ Wawancara dengan A (inisial), Perempuan yang bercerai, Ibu Rumah Tangga, pendidikan SMA, Padang, 11 September 2013.

${ }^{60}$ Wawancara dengan Zuarlis Saleh, Hakim Pengadilan Agama Padang, Padang, 18 September 2013.
} 
Bagi perempuan yang tidak bekerja dan tinggal dengan keluarga besarnya, mereka mengakui juga tidak takut bercerai dari suaminya, karena mereka merasa ada dukungan finansial dan psikologis dari orang tuanya. Di samping itu sebenarnya mereka juga mempunyai penghasilan tidak tetap. Secara lugas mereka mengatakan "kami akan tetap hidup tanpa dia" atau dengan ungkapan lain "kita tidak akan mati walapun tidak ada dia."61

Ada pula perempuan yang bercerai tidak memikirkan masalah finansial yang mungkin akan ditanggungnya setelah bercerai dari suaminya. Meskipun ia tidak mempunyai penghasilan tetap, tapi ia tinggal dengan orang tuanya dan ia yakin akan mendapat dukungan finansial dari orang tuanya. Seperti yang dinyatakan oleh salah seorang dari perempuan yang bercerai yang tinggal di rumah orang tuanya. Untuk apa takut bercerai, jika antara suami istri bertengkar hampir setiap hari. Meskipun tidak ada suami, si istri yakin akan mampu bertahan hidup. Pada waktu memutuskan bercerai saya tidak terlalu memikirkan masalah finansial. Hal terpenting adalah persoalan dengan suami dapat selesai dengan cepat. ${ }^{62}$

Keempat, mengajukan gugatan cerai adalah hak perempuan yang diberikan oleh undang-undang. Secara umum di dalam masyarakat berkembang pemahaman bahwa cerai adalah hak suami, hanya suami yang berhak menjatuhkan talak, kecuali ketika terjadi nusyuz oleh suami (suami mengabaikan tanggung jawabnya). Dalam keadaan seperti ini, perempuan dapat mengajukan gugatan cerai. Dengan lahirnya Undang-undang No. 1 tahun 1974 dan Peraturan Pemerintah No. 9 tahun 1975 kemudian KHI yang diatur berdasarkan Inpres No. 1 tahun 1991 memberi peluang bagi istri untuk mengajukan gugatan cerai ke pengadilan. ${ }^{63}$ Soasialisasi terhadap peraturan-peraturan ini meningkatkan kesadaran hukum perempuan. Seperti yang diakui oleh seorang perempuan yang mengajukan gugatan cerai, ia sudah lama mengetahui peraturan tentang perkawinan dari membaca buku. ${ }^{64}$ Perempuan mulai mengetahui, memahami bahwa ia dapat mengajukan gugatan cerai karena alasan-alasan tertentu yang diatur undang-undang dan peraturan perkawinan lainnya. ${ }^{65}$ Hal ini membawa perubahan persepsi perempuan mengenai perceraian itu sendiri.

Perubahan tingkat perceraian dan faktor penyebabnya, merupakan indikasi terjadinya perubahan sosial lainnya dalam masyarakat. Sistem sosial bergerak cepat atau lambat ke arah suatu bentuk sistem keluarga konjugal dan ke arah industrialisasi. Perubahan sistem keluarga menyesuaikan diri pada kebutuhan industrialisasi. Dengan industrialisasi keluarga tradisional (sistem keluarga besar) sedang mengalami kehancuran. ${ }^{66}$

\footnotetext{
${ }^{61}$ Wawancara dengan RLA (inisial), Perempuan yang bercerai, Pendidikan S1 PGTK, Pekerjaan Ibu Rumah Tangga, Padang, 10 September 2013.

${ }^{62}$ Wawancara dengan RLA (inisial), Perempuan yang bercerai, Padang, 10 September 2013.

${ }^{63}$ Peraturan Pemerintah No. 9 Tahun 1975 tentang peraturan Pelaksana Undang-undang No. 1 Tahun 1974 Tentang Perkawinan, pasal 19 jo. Pasal 116 Kompilasi Hukum Islam.

${ }^{64}$ Wawancara dengan N (inisial), Perempuan yang bercerai, guru, pendidikan PGTK, Padang, 18 September 2013.

${ }^{65}$ Wawancara dengan Yunedi, Panitera Muda Gugatan Pengadilan Agama Padang, Padang, 24 September 2013.

${ }^{66}$ William J. Goode, Sosiologi Keluarga (Jakarta: PT Bina Aksara, 1991), h. 210.
} 
Sanak saudara baik secara hubungan karena perkawinan ataupun karena hubungan darah secara relatif tidak diikutsertakan dalam pengambilan keputusan sehari-hari dalam keluarga konjugal. Setiap orang mempunyai kebebasan dan menentukan calon pasangan hidupnya sendiri dan selanjutnya pasangan suami istri lebih banyak berbuat terhadap kehidupan keluarga masing-masing. Keluarga luas (keluarga besar) tidak lagi menyangga pasangan suami istri, dan tidak banyak menerima bantuan dari kerabat, begitu juga sebaliknya. Keluarga luas lebih dapat bertahan daripada keluarga kecil yang terdiri dari suami, istri dan anak-anak. Oleh karena itu, angka perceraian dalam sistem keluarga konjugal cenderung lebih tinggi. ${ }^{67}$

Sebagaimana telah dikemukakan di atas, hasil penelitian di lapangan menunjukkan telah terjadi perubahan persepsi perempuan di Kota Padang mengenai perceraian. Persepsi yang terdapat di kalangan perempuan tersebut adalah 1) Bercerai bagi perempuan bukan lagi merupakan hal yang tabu dan memalukan. 2) Bercerai adalah solusi yang dapat diambil perempuan untuk menyelesaikan persoalan yang terjadi di antara suami isteri dalam rumah tangga. 3) Bercerai bukan lagi merupakan hal yang menakutkan. 4) Mengajukan gugatan cerai adalah hak perempuan yang diberikan oleh peraturan perundang-undangan terhadap perempuan yang menghadapi masalah dalam keluarganya. Persepsi tersebut berbeda dari persepsi perempuan dahulu, di mana perceraian bagi perempuan dianggap suatu hal yang tabu dan memalukan. Perempuan yang minta cerai dari suaminya dipandang negatif oleh masyarakat di lingkungannya. Perceraian merupakan hal yang menakutkan. Di samping itu perempuan dahulu juga berpendapat bahwa perceraian adalah hak suami.

Kondisi keluarga saat ini beserta segala hal yang mempengaruhinya memang dapat menimbulkan berbagai masalah dalam kehidupan sebuah keluarga. Tuntutan hidup keluarga saat ini memang tinggi. Tidak sama halnya dengan tuntutan hidup pada keluarga pada masa lampau. Tantangan kehidupan yang muncul di dalam kehidupan masyarakat kita juga telah menyebabkan berbagai masalah yang dihadapi sebuah keluarga pada saat ini. Hal ini seringkali menimbulkan masalah dan berdampak kepada keharmonisan keluarga. Ketika masalah tersebut tidak kunjung selesai dan ketika perempuan memiliki persepsi bahwa bercerai merupakan solusi yang bisa dilakukannya untuk menyelesaikan masalah ini, maka hal ini akan berpengaruh terhadap keputusan perempuan untuk bercerai dari suaminya. Semakin banyak perempuan yang berpendapat seperti ini maka akan semakin banyak perempuan yang akan mengajukan gugatan cerai ke Pengadilan Agama.

Bila perempuan menganggap bahwa bercerai bukan lagi sesuatu yang memalukan dan bukan pula hal yang tabu untuk dilakukan, maka ketika para perempuan menghadapi masalah dalam keluarganya atau konflik yang berkepanjangan dengan suaminya, maka mereka tidak takut lagi untuk mengambil keputusan bercerai dari suamiya. Apalagi bila perempuan mempunyai penghasilan sendiri, hal ini akan mempengaruhinya mengambil

\footnotetext{
${ }^{67}$ Ibid.
} 
keputusan untuk mengajukan gugatan cerai terhadap suaminya. Ia merasa tidak takut lagi menghadapi risiko yang harus dihadapinya pasca perceraian dari suaminya. Di mana ia harus menanggung segala kebutuhannya sendiri. Bahkan ia mungkin juga harus menanggung beban untuk mengurus, mendidik anak-anaknya dan sekaligus menanggung nafkah anakanaknya. Karena ia berkeyakinan bahwa ia akan mampu menanggung tugas-tugas tersebut tanpa suami.

\section{Kesimpulan dan Saran}

Berdasarkan temuan penelitian yang telah dipaparkan sebelum, ada beberapa kesimpulan penelitian yang dapat dikemukakan berikut ini. Faktor-faktor penyebab meningkatnya angka gugatan cerai di Pengadilan Agama Kelas I A Padang, yaitu: Meningkatnya tingkat pendidikan perempuan; Perempuan semakin sadar hukum; Adanya peluang berkarir bagi perempuan; Perubahan stigma masyarakat terhadap perempuan yang bercerai; Pengaruh teknologi informasi seperti media massa, baik media cetak maupun media ekektronik; Melemahnya lembaga perkawinan dan lunturnya pandangan perempuan terhadapnya; Melemahnya pemahaman nilai-nilai agama di kalangan perempuan. Kondisi ini berhubungan erat dengan perubahan yang terjadi terhadap persepsi perempuan tentang perceraian di Kota Padang. Di mana dari temuan penelitian dipahami bahwa perempuan memiliki persepsi bahwa: perceraian bukan merupakan hal yang tabu dan memalukan. Perceraian bahkan dianggap merupakan solusi untuk menyelesaikan permasalahan atau konflik berkepanjangan yang terjadi di dalam keluarga. Perceraian bukan sesuatu yang menakutkan. Mengajukan gugatan cerai bahkan merupakan hak perempuan yang diberikan oleh undangundang. Keberanian perempuan di Kota Padang untuk mengambil keputusan mengajukan gugatan cerai terhadap suaminya ke Pengadilan Agama Kelas I A Padang sangat berpengaruh terhadap banyaknya perkara gugatan cerai yang diterima dan diselesaikan oleh Pengadilan Agama Kelas I A Padang. Terjadinya perubahan persepsi perempuan di Kota Padang terhadap perceraian telah memberikan pengaruh besar bagi meningkatnya angka gugatan cerai di Pengadilan Agama Kelas I A Padang. Hal ini terlihat dari meningkatnya perkara gugatan cerai di Pengadilan Agama Kelas I A Padang dari tahun ke tahun. Dalam hal ini perubahan budaya membawa pengaruh terhadap persepsi perempuan tentang pernikahan dan perceraian.

Diharapkan hasil penelitian ini dapat memberikan kontribusi pemikiran dan masukan bagi para orang tua agar dapat memberikan pengetahuan dan pemahaman yang benar tentang kehidupan berumah tangga kepada anak-anaknya sehingga mereka dapat membentuk keluarga yang sakinah mawaddah wa rahmah serta mempunyai persepsi yang benar terhadap perceraian. Kepada kalangan akademisi dan para mubaligh agar melakukan penyuluhan hukum, memberikan pengetahuan dan bimbingan tentang cara mengatasi persoalan rumah tangga sesuai dengan nilai-nilai Islam. Di samping itu memberikan pengetahuan dan pemahaman yang benar terhadap perceraian, sehingga masyarakat mempunyai persepsi yang benar tentang perceraian dan angka perceraian di Kota Padang 
dapat ditekan. Kepada Badan Pemberdayaan Perempuan dan Perlindungan Anak Provinsi Sumatera Barat dan Kota Padang serta Kepala Seksi Pengembangan Keluarga Sakinah Kantor Kementerian Agama Propinsi Sumatera Barat dan Kota Padang diharapkan dapat melakukan kajian tentang fenomena gugatan cerai di Pengadilan Agama Padang dan perubahan persepsi perempuan di Kota Padang terhadap perceraian.

\section{Pustaka Acuan}

Asasriwarni dan Nurhasnah. Peradilan Agama di Indonesia. Padang: Hayfa Press, 2006.

Dahlan, Abdul Aziz, (ed.). Ensiklopedi Hukum Islam. Jakarta: Pt Ichtiar Baru Van Houve. Goode, William J. Sosiologi Keluarga. Jakarta: PT Bina Aksara, 1991.

http://www.badilag.net/2010/5/10, diakses 16 Juni 2011.

Koentjaraningrat, Metode-Metode Penelitian Masyarakat. Jakarta: PT. Gramedia, 1981.

Moleong, Lexy J. Metodologi Penelitian Kualitatif. Jakarta: Rosda Karya, 2004.

Peraturan Pemerintah No. 9 Tahun 1975 tentang peraturan Pelaksana Undang-undang No. 1 Tahun 1974 Tentang Perkawinan, pasal 19 jo. Pasal 116 Kompilasi Hukum Islam.

Putusan Nomor 117/Pdt.G/2009/PA Pdg.

Robbins, Stephen P. Organizational Behavour. Prentice-Hall International, 2001.

Salinan Putusan Pengadilan Agama Padang Nomor: 01/Pdt.G/2010/PA.Pdg.

Salinan Putusan Pengadilan Agama Padang Nomor: 1023/Pdt.G/2012/PA.Pdg.

Salinan Putusan Pengadilan Agama Padang Nomor: 1037/Pdt.G/2012/PA.Pdg.

Salinan Putusan Pengadilan Agama Padang Nomor: 117/Pdt.G/2009/PA.Pdg.

Salinan Putusan Pengadilan Agama Padang Nomor: 257/Pdt.G/2009/PA.Pdg.

Salinan Putusan Pengadilan Agama Padang Nomor: 303/Pdt.G/2010/PA.Pdg.

Salinan Putusan Pengadilan Agama Padang Nomor: 309/Pdt.G/2009/PA.Pdg.

Salinan Putusan Pengadilan Agama Padang Nomor: 418/Pdt.G/2009/PA.Pdg.

Salinan Putusan Pengadilan Agama Padang Nomor: 682/Pdt.G/2008/PA.Pdg.

Salinan Putusan Pengadilan Agama Padang: 244/Pdt.G/2009/PA.Pdg.

Sasroatmodjo, Arso dan A. Wasit Aulawi. Hukum Perkawinan di Indonesia, Cet. 2. Jakarta: Bulan Bintang, 1978.

Sudarsono. Hukum Perkawinan Nasional. Jakarta: Rineka Cipta, 1991.

Triwarmiyati D., M. “Tipologi Relasi Suami Isteri, Studi Pemikiran Letha Dawson Scanzoni dan Jhon Scanzoni", (Tesis: Universitas Indonesia, 2009.

Undang-Undang Nomor 3 Tahun 2006 tentang Perubahan Undang-Undang Nomor 7 Tahun 1989 tentang Peradilan Agama.

Winardi, J. Motivasi dan Pemotivasian dalam Manajemen. Jakarta: PT. Raja Grafindo, 2004. 